\title{
冠動脈れん縮の病態と臨床 (抄録)
}

\author{
熊本大学医学部循琂器内科 泰江弘文
}

\section{はじめに}

冠動脈のれん縮（冠れん縮）は異型狭心症のみなら ず，その他の狭心症や急性心筋梗塞など虚血性心疾患 全般の発生上も重要な役割を果たしている。ここで冠 れん縮とは心臓の表面を走行する比較的太い冠動脈が 異常に収縮して心筋の虚血を来した場合と定義する。 冠れん縮によって生ずる典型的な臨床症候群が異型狭 心症である，異型狭心症は安静時に出現し，心電図の STの上昇を伴うことを特徴とする.

\section{1. 異型狭心症の発作の日内変動}

巽型狭心症は特に夜間から早朝にかけての安静時に 出現し，通常は日中の運動によっては誘発されない。 図 1 はHolter心電図によって記録された異型狭心症 患者71例の発作の日内分布を示したものであるが，夜 間から早朝にかけてピータを有する著明な日内変動が みられることが理解される。しかも発作の67\%は自覚 症状のない，いわ幠痛性心筋虛血発作（silent myocardial ischemia)である. 黑型狭心症の発作は早 朝に山軽度の労作によっても誘発されるが，午後から はかなりの激しい労作によっても誘発されないのが普 通である。筆者らが異型狭心症患者90名に扝いて同じ 日の午前 $(7: 00 \sim 8: 00$ a.m. $)$ と午後 $(3: 00 \sim 4:$

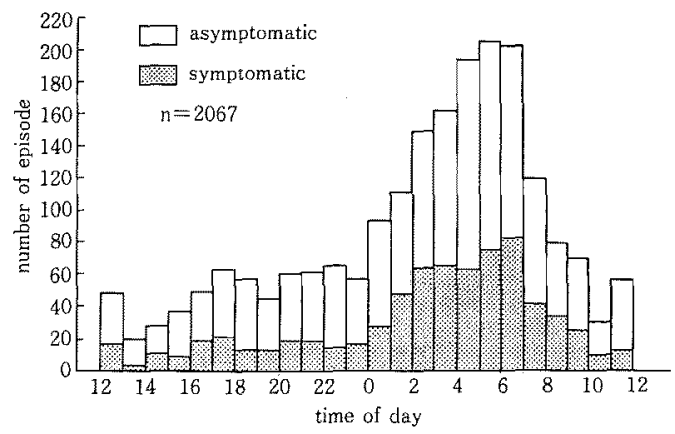

图 1。異型狭心症患者に抢引る心筋虚血発作の日内変 動。発作は夜間加ら早朝にかけて頻発していることが 示される。 00p.m.) にtreadmill運動を行ったところ, 午前には53 名（59\%）に抒いて発作が誘発されたのにもかかわら ず俕後から 30 名（33\%）においてのみ発作注誘発さ れた。つまり異型狭心症の患者に扔いては運動耐容能 の著明な日内変動が認められる，異型狭心症の発作， すなわち冠れん縮は何故, 安静時とくに夜間から早朝 の安静時に出現しやすく日中は運動によっても誘発さ れにくいのであ万うか. 異型狭心症患者において早朝 安静時, 並びに身体活動を行った後の午後の両方に冠 動脈造影法を行ってみると早朝安静時には冠動脈は トーヌスが年進について内径は狭小化しており, ニト ログリセリンの投与により著明に抎大し，又運動など によっても容易にその内径が完全に閉塞してれん縮に

$\%$

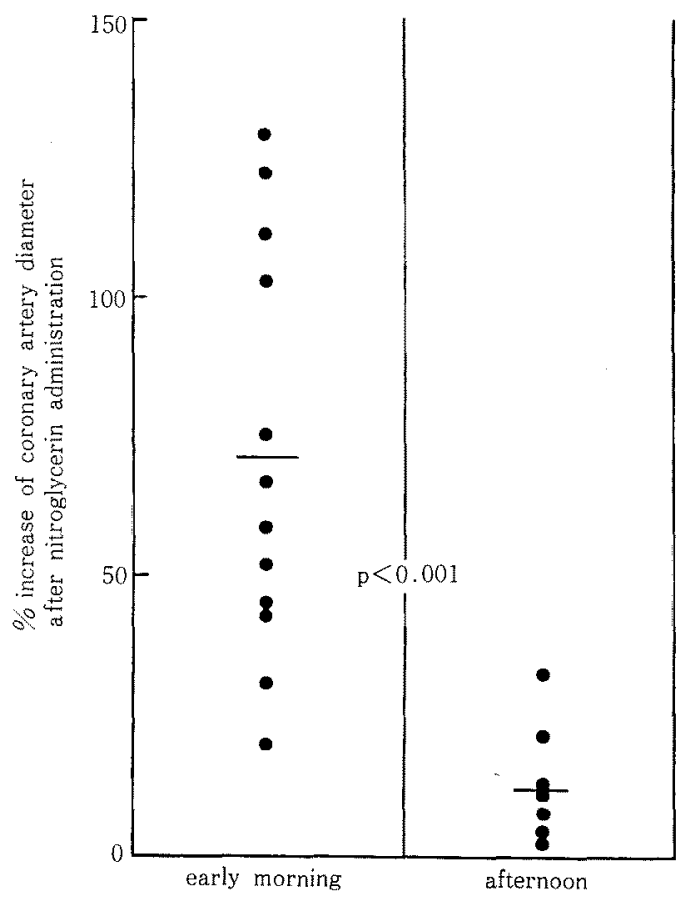

图 2. 型型狭心症患者に㧍讨る早朝及び午後において のニトログリセリンによる冠動脈内径の拡張率。 
陷る。ところが午後からは筧動脈は既に搪張しており ニトログリセリンによってもそれ以上はほとんど拡張 せず，又運動負荷などによってもれん縮は誘発されな いのが普通である．図 2 はニトログリセリンによる冠 動脈の内径の增加率を早朝と午後とで比較したもので あるが，早朝において蒄動脈はニトログリセリンに より著明に搪張するが，午後からはそれほど拡張しな いことが示されている．筆者ら屿冠れん縮が副交感神 経伝達物贒であるアセチルコリンの誘導体であるメサ コリンの皮下注射によって誘発されることを見いだし た.この反応は副交感神経遮断薬であるアトロピンに よって遮断されるのでムスカリン受容体を介するもの と思われる。しかしながらメサコリンの皮下注射によ り血压は低下した心拍数は増加するので交感神経も刺 激されると考えられるので $\alpha$ 受容体を介する交感神経 の関与も否定出来なかった。

\section{2.アセチルコリンと冠れん縮}

筆者らはアセチルコリンを直接冠動脈内に注入する ことにより，全身の血行動態の変動なしに高率の異型 狭心症患者に抢いて冠れん縮を誘発しうることを見い だした。筆者らの経験では異型狭心症患者107例中99例 (93\%)に抢いて冠れん樎が誘発された。これに対して 非異型狭心症患者に招いては102例中 4 例（4\%）に招 いてのみ冠れん縮は誘発されたに過ぎなかった。この 反応はアトロピンにより遮断される。従ってアセチル
コリンはムスカリン受容体を介して直接に冠れん縮を 誘発すると考えられる。冠れん縮が誘発された冠動脈 の70\%注正常であるが，又は有意の器質的狭窄を有し ていなかった。ところでアセチルコリンは血管内皮が 正常であれば血管を拡張させるが内皮を槑離したり， あるい汁内皮に傷害があると血管を取縮するが，これ 㹥血管の内皮が正常であればムスカリン受容体の刺激 に上り内皮由来の弛緩因子：endothelium-derived relaxing factor (EDRF) が分泌され，しかもEDRFは NOであることが明らかにされた。一方, 動脈硬化の発 生には内皮の傷害が必須であることが知られている. したがって，冠れん縮を有する患者はすべて，冠動脈 造影像の所見のいかんにかかわらず，その冠動脈に内 皮傷害つまり動脈硬化を有している可能性がある。筆 者らは冠動脈造影像上，冠動脈が正常で，しかも虚血 性心疾患を有しない患者において冠動脈の内径のアセ チルコリンの冠動脈内注入に対する反応を調べた，図 3 はその結果を示すが，29歳以下の若年者群では左冠 動脈前下行枝の近位部位を除いてすべての冠動脈揖よ び冠動脈部位はア七チルコリンに対して拡張または拡 張の傾向を示した。これに反して，30歳以上の中高年 者群においてはアセチルコリンはずでての冠動脈扔よ びその部位を収縮させ，あるいは収縮の傾向を生じさ せた。一方，内皮非依存性の弛緩物質であるニトログ リセリンはすべての冠動脈㧍よびその部位を拡張さ せ，しかも若年者群と中高年者群との間にはこの反応

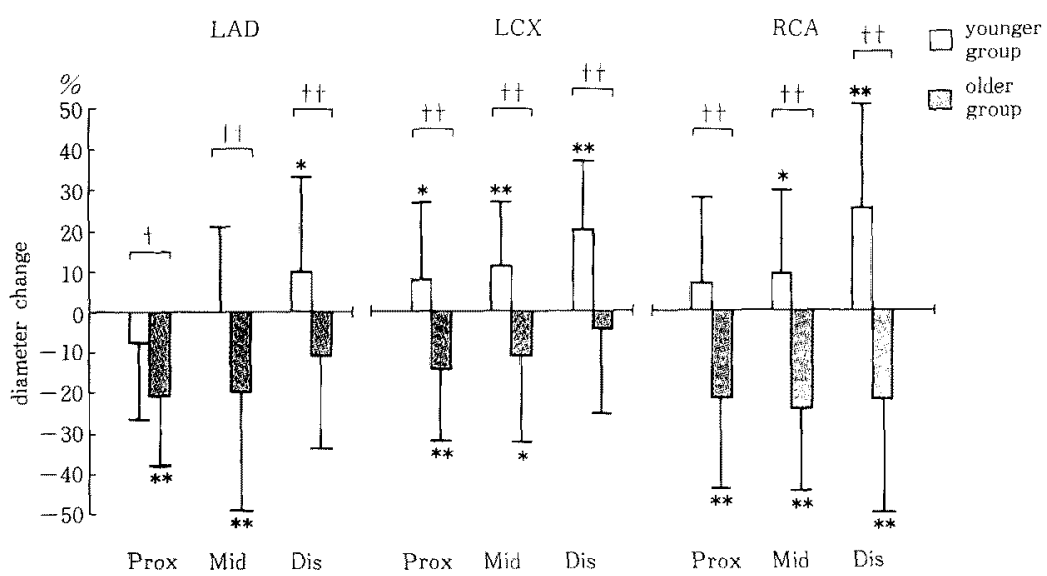

図 3.アセチルコリン $50 \mu \mathrm{g}$ 冠動脈内注入による冠動脈内径の反応、若年者群ではア セチルコリンにより左冠動脈前下行枝近位部以外のすべての冠動脈は拡張ないしは拡 張の傾向を示したが，中高年者群では逆にすべての冠動脈のすべての部位で収縮ない しは収縮の傾向を示した。 


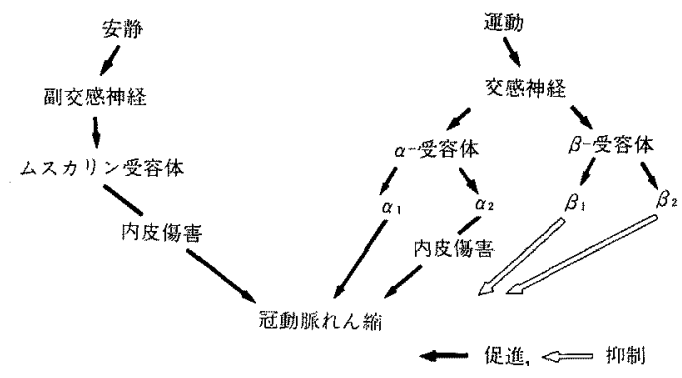

図 4、自律神経と冠動脈れん縮との関係.

に差は認められなかった。従って,アセチルコリンに 対する冠動脈の反応の若年者群と中高年者群における 差は内皮の差によるものであると結論される.さらに， 30歳以上の中高年者に括いては例之冠動脈造影像上, 正常な冠動脈を有していてもその冠動脈には内皮の機 能障害が存在すると推定される。明らかな冠動脈硬化 を有する患者に扔いてはアセチルコリンは冠動脈造影 所見の異常の有無にかかわらず，すべての冠動脈抢よ びその部位を収縮させた。これに反して二トログリセ リンは冠動脈造影所見の異常の有無にかかわらず，す べての冠動脈およびその部位を拡張させた。従って， 生体に肪けるヒ卜冠動脈のアセチルコリンに対する反 応は内皮の傷害の有無により異なると思われる。

\section{3、冠れん縮と自律神経との関係}

筆者らは冠れん縮と自律神経との関係を図 4 に示す ごとく考えている. 安静時には副交感神経の活動が亢 進し，日中の運動時には低下することは上く知うれて いる. 副交感神経の活動が亢進するとその末端からア セチルコリンが分泌されてムスカリン受容体を刺激 し，内皮が傷害されている場合は盘管の収縮を来す。 異型狭心症の場合は冠動脈の平滑筋が過収縮しやすく なっているので冠れん縮にまで陷る，すでに述べたご とくれん縮は特に夜間から早朝に安静時にかけて出現 しやすく，日中は運動によっても誘発されにくいが， これは前述の事実と関連があると思われる。一方，運 動によっては交感神経が刺激されるが，交感神経には $\alpha$ 受容体と $\beta$ 受容体があり，前者は血管収縮を後者は血 管拡張を来す， $\alpha$ 受容体にはさらに $\alpha 1$ と $\alpha 2$ 受容体があ る. $\alpha 2$ 受容体の刺激もまたEDRFを分泌させることが 明らかにされた，交感神経が早朝におけるごとく烸 に刺激されると $\alpha$ 受容体の活動が優位になることが知
られている.したがって早朝には軽い労作によっても $\alpha$ 受容体の刺激により冠動脈法収縮しやすくなると考 えられるが，内皮傷害つまり動脈硬化があるとこの収 縮はさらに増強され異型狭心症患者の場合は冠れん縮 にまで至ると思われる。一方, 交感神経が持続して刺 激されると $\beta$ 受容体の活動が優位になることが知られ ているので, 午後からは血管は拡張しており運動に よっても冠れん縮は誘発されにくいと思われる。また， 動眽硬化による内皮傷害のためのNOの低下のみで冠 れん縮の発生機序を十分に説明出来るわけでもない. 何故なら動眽硬化を有する冠動脈はすべて冠れん縮に 陷るわけではないからである。

\section{4. 冠れん縮とNO}

冠れん縮患者の冠動脈は内皮依存性弛緩物質である アセチルコリンやヒスタミン，エルゴイヴィンなどに より異常に収縮しまたニトログリセリンにより著明に 揬張する。ニトログリセリンは生体内でNOとなり血 管を搪張することが知られNOは内因性亜硝酸薬と称 されている. 従って冠れん縮患者の冠動脈内皮加の NOの産生は障害されていると考えられるが, NOは内 皮に存在するNOsynthase (NOS)によりアルギニンか ら生成されるので冠れん縮患者の冠動脈内皮NOSに 巽常がある可能性がある。冠れん縮患者の内皮NOSに 異常があるかいなかを分子生物学的な手法を用いて目 下検討中である.

\section{5. 冠れん縮の凝固・線溶系}

急性心筋梗塞の原因としては冠動脈血栓による閉塞 が考えられている。しかしながら冠れん縮も又急性心 筋梗塞の原因たりうる. 筆者等は生体内トロンビン生 成の鋭敏な指標であるフィブリノペプチドAが冠机ん 縮の発作後に血漿で上昇することから冠れん縮が冠血 栓, 延いては急性心筋梗塞の引き金となることを明ら かにした. 又, 血獎フィブリノペプチドAは冠れん縮の 発作と平行して著明な日内変動を示す。

\section{おわりに}

冠れん縮は異型狭心症のみならず虚血性心疾患全般 の発生上も重要な役割を果している．アセチルコリン の冠動脈内注入は異型狭心症患者の $93 \%$ において冠れ ん縮を誘発しうるが, アセチルコリンは若年者で冠動 脈が正常な例では冠動脈を拡張する。一方, 中高年者 
や明らかな冠動脈硬化のある症例では逆に冠動脈を収 縮させる。これはアセチルコリンは血管が正常であれ ば内皮からEDRF/NOを放出させることにより血管を 㹡張させるが，動脈硬化があって内皮が傷害されてい ると冠動脈平滑筋に対する直接の収縮作用により血管 を収縮させるためであると考えられる，冠れん縮患者 の冠動脈はアセチルコリンにより異常に収縮し, 又 NO供給物質であるニトログリセりンにより著明に拡 張する. 従って, 冠れん縮患者の冠動脈内皮でのNOは 不足していると考えられる.アセチルコリン活副交感 神経の神経伝達物質であり，しかも交感神経の活動は 安静時に光進し，運動時には低下するので以上の事実 は冠れん縮の発作が何故に安静時に出現しやすく，日 中は運動によって誘発されにくいかを説明できると思
われる。

\section{文献}

1) Yasue $\mathrm{H}$, et al: Coronary arterial spasm in ischemic heart disease and its pathogenesis. Circ Res 52 (suppl. 1) : 47, 1983.

2) Yasue $\mathrm{H}$, et al: Induction of Coronary artery spasm by acetylcholine in patients with variant angina: possible role of the parasympatheitc nervous system. Circulation $74: 955,1986$.

3) Yasue $H$, et al: Response of angiographically normal coronary arteries to intracoronary injection of acetylcholine by age and segment: possible role of early coronary atherosclerosis. Circulation $81: 482,1990$. 